\title{
THE STUDENT'S METACOGNITIVE SKILLS OF PROSPECTIVE PRIMARY SCHOOL TEACHERS
}

\author{
Ika Maryani ${ }^{*}$, Muhamad Arif Alhakim², Rivan Gestiardi3 \\ 1,2 Universitas Ahmad Dahlan, Yogyakarta, Indonesia \\ 3 Universitas Sebelas Maret, Surakarta, Indonesia \\ *ika.maryani@pgsd.vad.ac.id
}

\begin{abstract}
Article Info
\section{Article history}

Received January 17, 2021

Revised March 3, 2021

Accepted March 29, 2021

Keywords: Metacognitive skills; Prospective teacher; Primary school.

ABSTRACT

Metacognitive skill is essential to have by every individual, including the prospective teachers' students. Some teachers who have not trained in metacognitive ability would be caused by the lack of understanding of the stages in carrying out metacognitive ability. It has not realised that metacognitive ability can affect students' learning process and learning outcome. The students who have the excellent metacognitive ability can develop metacognitive domainoriented learning. This study aims to know the metacognitive skills of prospective primary school teachers in Universitas Ahmad Dahlan. This research used a quantitative approach to descriptive type and survey method. The samples are 100 students of elementary school education of Universitas Ahmad Dahlan consisting of the semester II, IV, and VI. The instrument used Metacognitive Ability Inventory (MAI) with the Likert scale (1-5). Data were analysed using descriptive statistics to determine the Mean, standard deviation, percentage, and metacognitive categorisation of elementary school education students. The research result showed a low-medium range category. It is influenced by some factors related to the inadequate metacognitive development of prospective primary school teachers. Judging from the cognitive knowledge aspect, the high category of the percentage calculation of cognitive knowledge aspects is in the declarative knowledge aspect. In the cognitive regulation aspect, planning becomes the highest percentage of cognitive regulation aspect.
\end{abstract}

\section{INTRODUCTION}

In this era, the students must develop personal ability independently by utilising the existing technology to encounter the globalisation era's challenges. Education currently focuses on the contextual problem, which is not limited to increasing students' intelligence and facilitating problem-solving skills. The students must hone the ability to overcome the challenges, such as critical thinking skills, metacognitive ability, communication ability effectively, and innovating. It requires problem-solving ability, critical, creative, systematic, and logical-thinking oriented learning systems (Hsu \& Wang, 2018). All of the abilities must be developed in the school environment and in developing individual potential outside school hours. These abilities are essential to be a provision in encountering the challenges (Zhao et al., 2014). 
A good learning process increases the quality of education. The quality of education influences the country's development and progress (Masino \& Niño-Zarazúa, 2016; Skinner et al., 2013). Successful learning was proved by behaviour changes as the experiences' results (Black \& Schwartz, 2015; Oxman \& Wong, 2014). Currently, the students in Indonesia can not tell that they can face the globalisation era's challenges. Hayati et al. (2016) stated that Indonesia's learning still does not encourage students' critical thinking. Learning delivered does not encourage the students to think critically and only provides the material even though critical thinking is a challenged competence in the 21 st century.

One of the abilities required by the prospective teachers is metacognitive ability. Metacognitive skill is essential to have by every individual, including the prospective teachers' students (Jiang et al., 2016; Memnun et al., 2012). The lack of teacher knowledge about metacognitive ability makes this ability challenging to achieve in the learning process. Costillas (2016)argued that critical thinking is a challenge for teachers since their critical thinking ability is still weak. Efendi (2013) presented the survey result about a teacher's ability to carry out public and private secondary school teachers' metacognitive ability in Sidoarjo. The survey result showed that $11,37 \%$ of teachers had developed the metacognitive ability, while $88,63 \%$ never had. Some teachers who have not trained in metacognitive ability are caused by the lack of understanding of the stages in carrying out metacognitive ability. It has not realised that metacognitive ability can affect students' learning process and learning outcome.

Afifi et al. (2016) stated that the teacher training and education department, an institution that managed the educators in Indonesia, is responsible for producing professional teachers through a qualified learning process. Learning process standard in LPTK as stated in Permendikbud Number 49 of 2014 of National Standard for Higher education (SNPT) article 10 paragraph 2 explained the characteristic learning process in the college consisted of the character of interactive, holistic, integrative, scientific, contextual, thematic, practical, collaborative, and student-centred (Permendikbud No. 49 Tahun 2014 Tentang Standar Nasional Pendidikan Tinggi, 2014).

Metacognitive refers to knowledge about cognitive regulation and activities in the learning process (Febrina \& Mukhidin, 2019). The students of prospective teachers who have the metacognitive ability referred to be successful in the academic field also believed to facilitate their students well in the future (Jiang et al., 2016; Memnun et al., 2012; Saputri, 2017; Zhao et al., 2014). Metacognitive ability is pivotal in learning the learning activity and helps the students determine how to use their cognitive knowledge well (Blakey \& Spence, 1990; Demirel et al., 2015). It is influenced by the student's prospective teacher's awareness about the things that students must require in making a teaching plan up to evaluating the learning process to lead the positive impact toward student learning outcome. 
Metacognitive is second-order cognition, which means thinking about thinking, knowledge about the knowledge, or reflection about the actions. Two metacognitive components are declarative knowledge and skill procedural, strategy, and sources required to carry out the tasks. It also includes knowing what to do, how to do it, knowing the prerequisite to convince the task completeness, and knowing when to do it (Iskandar, 2014; Dirgantoro, 2018; Smith \& Hudson, 2013). In other words, the metacognitive experience is the conscious consideration in which the experience of the intellectuality accompanying every failure or successfulness in learning or different cognitive experiences (Veenman et al., 2006).

This study aims to know the metacognitive ability of prospective primary teachers in Universitas Ahmad Dahlan. For prospective teachers, knowing their metacognitive ability, it is expected that prospective teachers can apply the metacognitive ability to the students. This study also expected to improve the teacher's awareness about the importance of metacognitive ability. Furthermore, based on the background mentioned above, the researcher formulates the problem in this research "How metacognitive ability on the students of primary school teacher education of Faculty of Teacher Training and Education of Universitas Ahmad Dahlan is."

Government regulations number 30 of 1980 article 2 paragraph 1 mentioned that the purpose of higher education is: 1) preparing the students to be a community member who has the academic ability and/or to be a professional who can apply, develop, and/or enrich knowledge, technology and/or art; and 2) developing and disseminating knowledge, technology, and/or art also strives to improve people's lives and enrich national culture. Henschke (2011) and Loeng (2018) stated that andragogy is the application of humanistic principles. Transformational learning can be carried out by explaining how adults interpret their lives and interpret their lives. The explanation of life experience can give meaningful meaning and provide the opportunity to change the perspective. Carpenter-Aeby \& Aeby Victor (2013) and Conaway (2009) mentioned that andragogy literally could be interpreted as knowledge and art of teaching an adult. However, because the adult is an individual who can self-directed, the important andragogy student learning activity is not a lecturer teaching activity.

According to Flavell, Iskandar (2014) introduced the metacognitive term. Metacognitive activity is the activity of "thinking about thinking" that consciously controls its cognitive process. Meanwhile, according to Schraw \& Dennison (1994) and Schraw et al. (2012), metacognitive ability indicators stated that metacognitive ability could be seen at least from two learning processes. First, cognitive knowledge encompassing self-declarative knowledge and procedural knowledge strategy about the use of the strategy. Declarative knowledge consists of self-understanding, while procedural knowledge consists of how someone uses the learning strategy, and conditional knowledge encompasses when and why the strategy is used. Second, cognitive regulation that there are cognitive aspects are: 
1) Goals' planning that will achieve is the strategy planned to achieve the goals, 2) The information management strategy covers the skills and the strategy in organising the information efficiently, summarising the information, and sorting out the information, 3) Monitoring the understanding is to know self-understanding on how far it can master the materials and use the strategy appropriately, 4) The strategy's suitability is that it can know the strategy to correct mistakes in the understanding process, and 5) Evaluating is by controlling learning strategy, whether it is appropriate and when to use the appropriate strategy.

According to the theory mentioned above, this research is instrumental in effectively presenting the learning process. The learning process referred to is the whole emotional, behavioural, social and cognitive involvement of students in every learning activity. It is evident in his involvement during the learning process with any model. By analysing the student's metacognition profile, it hoped that it could become a reference for determining appropriate learning and learning methods to improve students' metacognitive abilities. The results of the analysis can be used as basic and advanced materials related to future metacognitive abilities.

\section{METHODS}

The research type used in this research was quantitative descriptive research. According to Sukmadinata (2017), descriptive research is the most basic form of research. Quantitative descriptive research presents the data of a population measured by using the collection technique of quantitative data. The research method used in this research was the survey method-this study conducted in Campus 5 of Universitas Ahmad Dahlan, Yogyakarta. Place selection considered the students of primary school teacher education of semester II, IV, and VI in Universitas Ahmad Dahlan. The researcher conducted the study during a month starting from April 20, 2019, to May 30, 2019.

The researcher chose the students of primary school teacher education students of semester II, IV, and VI of Universitas Ahmad Dahlan as the population in this study. One hundred students every semester who participated as a part of the population took part in this research. Therefore, it reflected all of the students of a primary school teacher of Universitas Ahmad Dahlan. The research only used a metacognitive variable as a single variable. It meant that the variable used was only one variable. It caused that the researcher would know the metacognitive ability of the students of a prospective teacher in Universitas Ahmad Dahlan by using an inventory test to collect the data regarding student's metacognitive ability.

The instrument used was an inventory of metacognitive ability. Inventory consisted of the number of questions to know the respondent's metacognitive ability. The inventory was made based on the characteristic of metacognitive ability. 


\section{RESULTS AND DISCUSSION}

\section{RESULTS}

Data that existed in this research is the metacognitive ability of primary school teacher education of Universitas Ahmad Dahlan divided into several data types or respondent categories of semester II, IV, and VI, and the whole respondents' data analysis.

\subsection{Data Analysis of Semester II}

The data analysis of semester II would find Mean, Median, Mode, and Standard Deviation. Also, it needed to look for the highest and lowest score. The SPSS program's calculation found the Mean of 150,76, Media of 150, Mode of 150, and Standard Deviation of 4,54 . The highest score of respondents in semester II groups is 166 , and the lowest score is 145.

Table 1. Data Analysis Result of Semester II

\begin{tabular}{lll}
\hline No & Types of Calculation & Result \\
\hline 1 & Mean & 150.76 \\
2 & Median & 150 \\
3 & Mode & 150 \\
4 & Standard Deviation & 4.57 \\
5 & Maximum Score & 166 \\
6 & Minimum Score & 145 \\
\hline
\end{tabular}

According to table 1, it can conclude that $70 \%$ of respondents are in a low category, $21 \%$ of respondents are in the medium category, and $9 \%$ are in the high category.

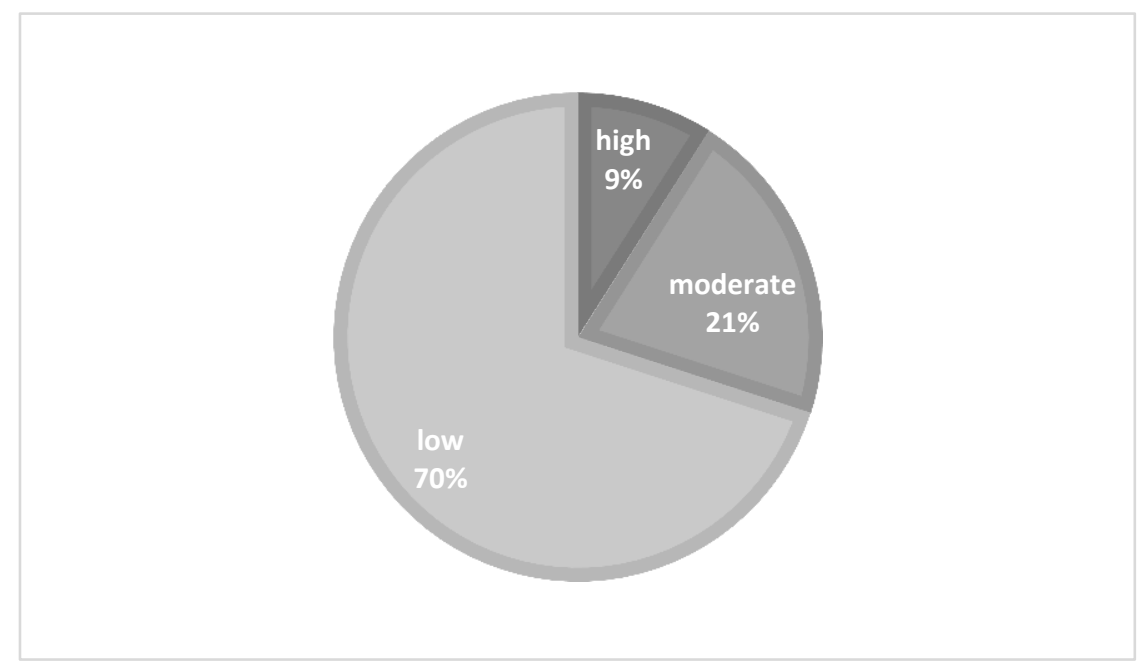

Figure 1. Pie Chart of Score-Category of Semester II

\subsection{Data Analysis of Semester IV}

The data analysis of semester IV would find Mean, Median, Mode, and Standard Deviation. Also, it needed to look for the highest and lowest score. The spss program's 
calculation found a Mean of 148,95, Median of 149, Mode of 148, and Standard Deviation of 3,05 . The highest score of respondents in semester IV groups is 162 , and the lowest score is 143.

Table 2. Data Analysis Result of Semester IV

\begin{tabular}{lll}
\hline No & Types of Calculation & Result \\
\hline 1 & Mean & 149.39 \\
2 & Median & 149 \\
3 & Mode & 148 \\
4 & Standard Deviation & 3.53 \\
5 & Maximum Score & 162 \\
6 & Minimum Score & 143 \\
\hline
\end{tabular}

According to table 2, it can be stated that the respondents of semester IV are in the low group category, about $27 \%, 68 \%$ is in the medium group category, and $5 \%$ is in the high group category. The scoring category of respondents of semester IV also can be seen in the Pie chart below.

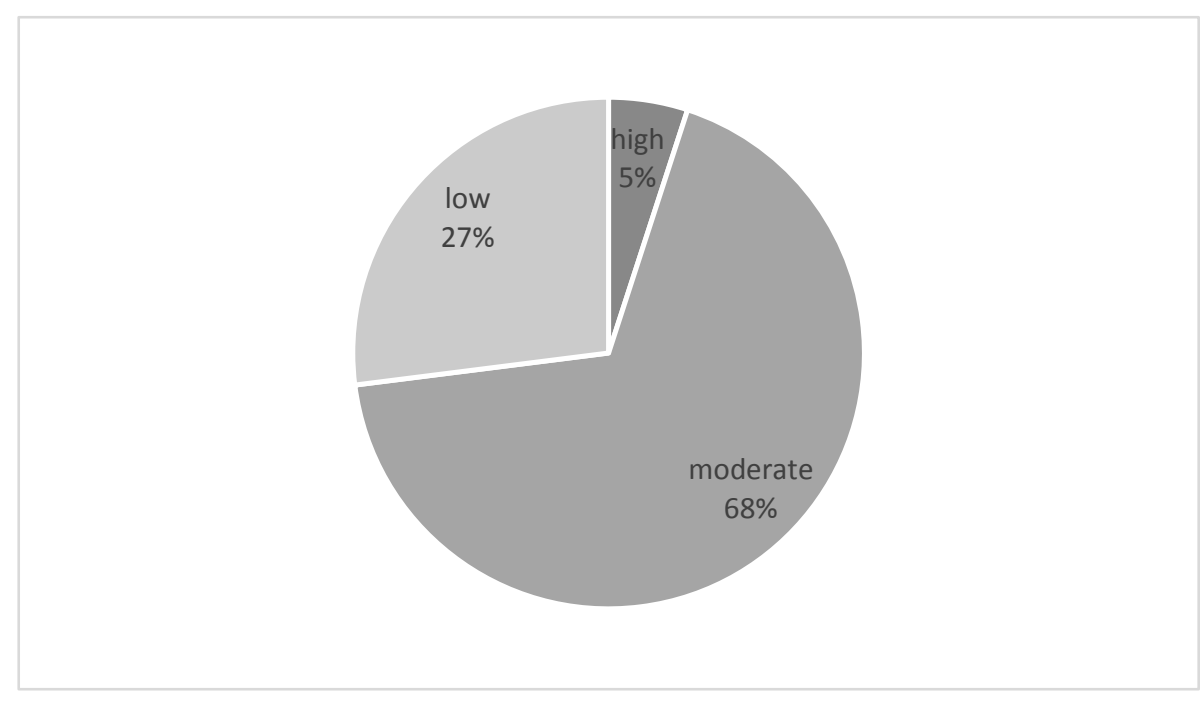

Figure 2. Pie Chart of Score-Category of Semester IV

\subsection{Data Analysis of Semester VI}

The question items obtained the highest score of 167, the lowest score of 144, Mean of 150,55, Median 150, Mode of 151, and Standard Deviation of 4,82, as shown by the table below.

Table 3. Data Analysis Result of Semester VI

\begin{tabular}{lll}
\hline No & Types of Calculation & Result \\
\hline 1 & Mean & 150.55 \\
2 & Median & 150 \\
3 & Mode & 151 \\
4 & Standard Deviation & 4.82 \\
5 & Maximum Score & 167 \\
6 & Minimum Score & 144 \\
\hline
\end{tabular}


From the calculation result of the categories, it can be stated that $69 \%$ is in the low group, $24 \%$ is in the medium group, and $7 \%$ is in the high group. The data of the score category of semester VI can also be seen in the chart below.

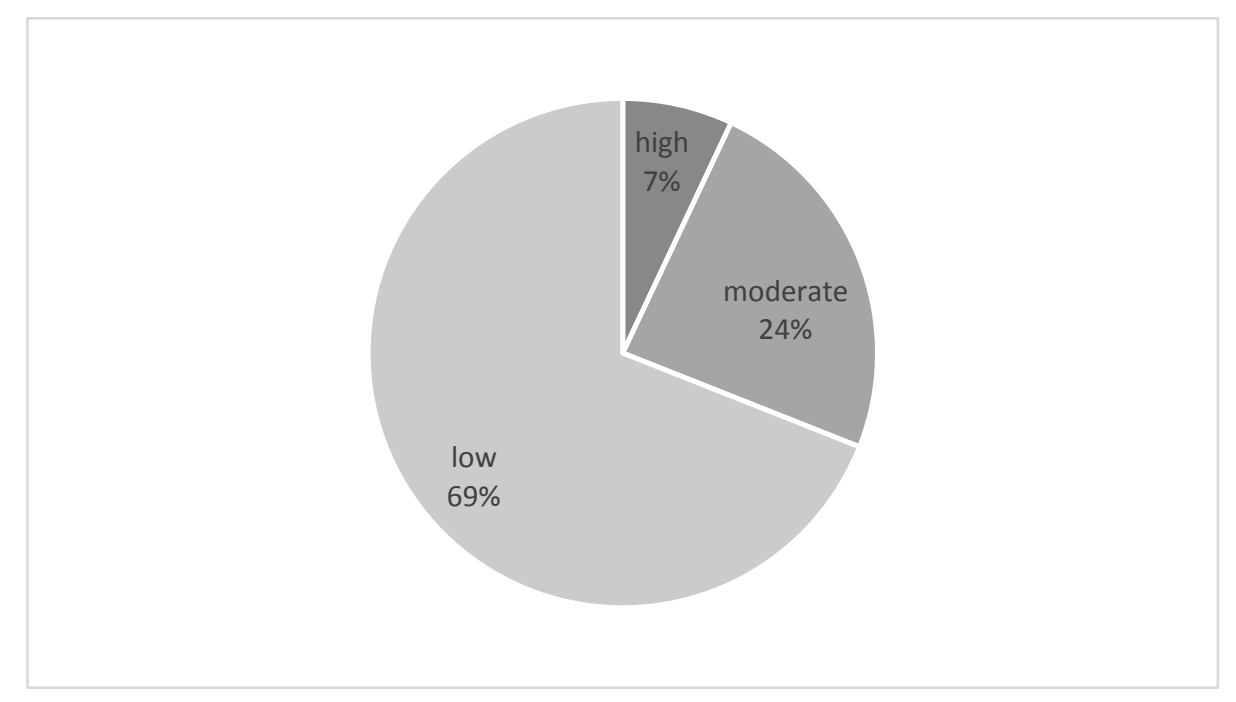

Figure 3. Score Category of Semester VI

\subsection{Data Analysis of all Respondents}

Data analysis of all respondents carried out with the same calculations as previous calculations. It will find a Mean, Median, Mode, Standard Deviation, the highest score, and the lowest score. The spss program's calculation obtained a Mean of 150,22, Median of 150, Mode of 151, and standard deviation of 4,35. While the highest score obtained of 167 , and the lowest score is 143.

Table 4. Data Analysis Result of Semester VI

\begin{tabular}{lll}
\hline No & Types of Calculation & Result \\
\hline 1 & Mean & 150.22 \\
2 & Median & 150 \\
3 & Mode & 151 \\
4 & Standard Deviation & 4.35 \\
5 & Maximum Score & 167 \\
6 & Minimum Score & 143 \\
\hline
\end{tabular}

It can be stated that the respondents in the low group are about $60 \%$, in medium groups, about $34 \%$, and the high group, about $6 \%$. The scoring category of the whole respondents can also be seen in Pie chart below. 


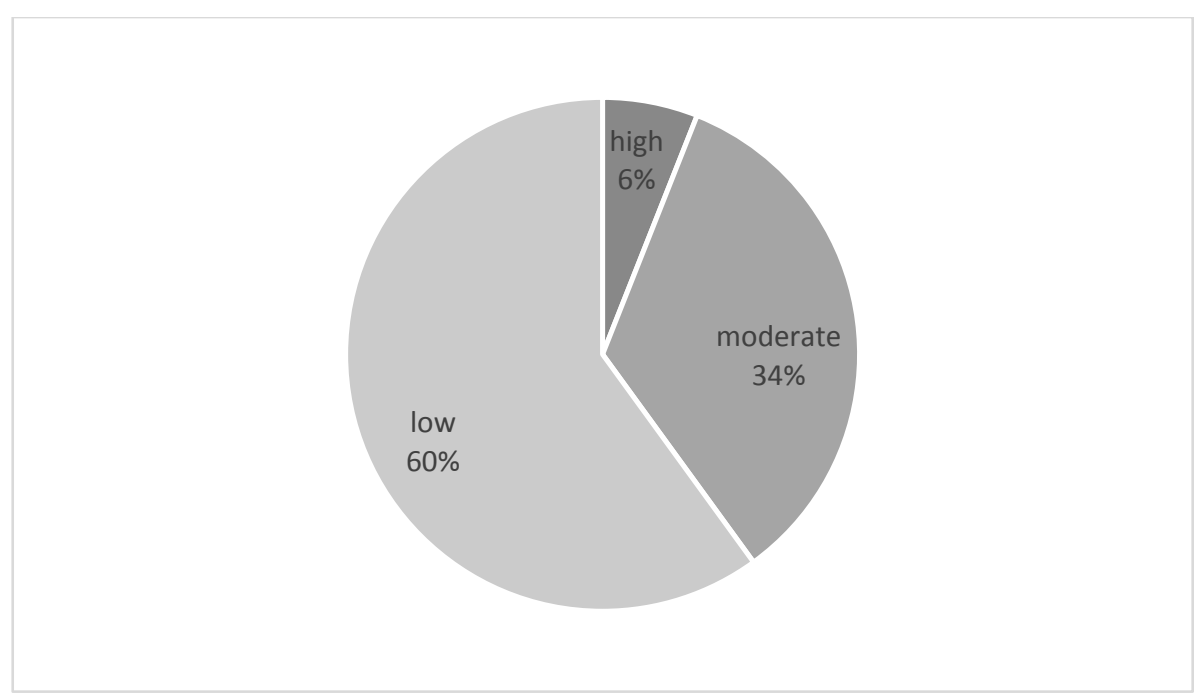

Figure 4. Pie Chart of Score-Category of All Respondents

\subsection{Data Analysis of Metacognitive Ability Aspect}

This part presents the whole respondents' data through metacognitive ability consisting of cognitive knowledge and cognitive regulation. Cognitive knowledge encompasses declarative knowledge, conditional knowledge, and procedural knowledge. Meanwhile, cognitive regulation encompasses the planning and organising the information.

Table 5. Percentage of Metacognitive Ability Aspect

\begin{tabular}{|c|c|c|c|}
\hline \multirow{2}{*}{ Metacognitive Ability Aspect } & \multicolumn{3}{|c|}{ Percentage (\%) } \\
\hline & High & Medium & Low \\
\hline \multicolumn{4}{|l|}{ 1. Cognitive Knowledge } \\
\hline a. Declarative Knowledge & $13.90 \%$ & $52.80 \%$ & $33.30 \%$ \\
\hline b. Procedural Knowledge & $13.30 \%$ & $79.00 \%$ & $7.80 \%$ \\
\hline c. Conditional Knowledge & $2.30 \%$ & $44.70 \%$ & $53.10 \%$ \\
\hline \multicolumn{4}{|l|}{ 2. Cognitive Regulation } \\
\hline a. Planning & $7.80 \%$ & $52.40 \%$ & $39.80 \%$ \\
\hline b. Organising the information & $1.60 \%$ & $34.00 \%$ & $64.40 \%$ \\
\hline c. Monitoring the understanding & $11.70 \%$ & $55.70 \%$ & $32.70 \%$ \\
\hline d. The suitability of the strategy & $4.20 \%$ & $44.30 \%$ & $51.50 \%$ \\
\hline e. Evaluation & $5.20 \%$ & $45.60 \%$ & $49.20 \%$ \\
\hline
\end{tabular}

Based on table 5, it can see that metacognitive ability is seen according to its aspect. The highest percentage is the declarative knowledge aspect of about $13,90 \%$, while the lowest percentage is organising the information, about 1,60\%. Table 5 also shows that in the cognitive knowledge aspect, students are in the low-medium category. It can be seen from the achievement of medium declarative knowledge, medium procedural knowledge, and common conditional knowledge. While the cognitive regulation aspect is also in the lowmedium category, as indicated by the medium planning aspect, low organising the 
information, medium monitoring, and understanding, d. The suitability of the strategy is low, and evaluation is low.

\section{DISCUSSION}

This study aims to know the metacognitive ability of prospective primary school teachers in Universitas Ahmad Dahlan. To answer problem formulation, the researcher needs to know the cause and effect of the conducted research. Therefore, it can be identified from data analysis results in table 1, table 2, table 3, and table 4 about students' respondent category in semester II, IV, and VI. From the data analysis result, it obtained that the average score varied between low to medium. This score is low compared to the 0-100 range scale for integrated tests into cognitive learning. It means that most students cannot monitor their thought process to have the maximum score yet. The results align with previous research that student metacognitive skills in some colleges have not yet developed maximally (Amin et al., 2020; Naimnule \& Corebima, 2018). It is influenced by personal knowledge, cognitive strategies, and organising and controlling the strategies to be applied in studying, thinking, and problem-solving. Despite this, monitoring and controlling affect metacognition (Chiu, 2009; Koriat et al., 2006).

One of the attempts of developing metacognitive ability is by considering the difference in the academic background so that the students who have the high and low academic ability can achieve the learning achievement (Corebima Aloysius et al., 2017; DiFrancesca et al., 2016; Maqsud, 1997). It is suitable with the analysis result that has differed to several data types or research response categories. The aim of this is by noticing any academic background differences at every semester level. The results showed a low-medium achievement on each indicator in knowledge and regulation aspects, as shown in Table 5.

Table 5 shows that the aspects of the students of primary school teacher education measured overall can identify that overall cognitive knowledge indicators are in the medium category. It relates to the cognitive ability that is descriptive, procedural, and conditional, even though they have not realised these three aspects. That is affected these three aspects are the metacognition knowledge namely awareness and control of its metacognitive abilities is not maximised, so that it required to know what is known as the information used by someone at the time of thinking, this case furthermore relates to declarative knowledge, procedural knowledge, and conditional knowledge. The research shows unsatisfactory results due to several factors that may occur, including the lack of understanding of students about their strengths and weaknesses in learning, less than optimal student involvement in determining their learning strategies, lack of student awareness of their learning styles, and the use of learning models that do not allow students to actively involved emotionally, socially, behaviorally, and cognitively. The involvement of metacognitive knowledge is 
significant to have by the students since the metacognitive knowledge can overcome the problems, solve the problems, and build the awareness of the subjects toward the knowledge they want to achieve (Maryani et al., 2020). Metacognitive knowledge makes the students aware of their advantages and limitations in understanding their failure and correcting it. Therefore, this study's results can be used as a reference for the elementary school education department to improve students' metacognition through various training and learning methods.

The above-mentioned description is needed to improve metacognitive awareness to regulate the learning and be aware of everything they do not understand. Therefore, it can be used as a reference to improve the learning outcome. The analysis results in cognitive regulation indicators shown in Table 5 obtained medium category overall. It meant that the student's self-regulation ability had not yet optimally proven by the score they obtained. The regulation is the level whereby the participants are actively involved by the metacognition, motivation, and attitude in the learning process (Zimmerman \& Martinez-Pons, 1990). There are three essential elements in the ability of regulation; 1) the strategy of metacognition in planning, organising, and monitoring cognition, 2) organising and controlling the effort to finish academic tasks, 3) the strategy of cognition used to think, remember, and understand (Pintrich \& De Groot, 1990). The research results showed that regulation's ability positively contributes to many aspects of life, such as education, social, culture, and others.

To improve cognitive regulation ability, the educators such as lecturer and teachers must instil the importance of internal motivation, use the learning strategy that is not only the activities of remembering but also involves the elaboration strategy, instil the importance of questioning or help-seeking, and be able to develop the cognitive strategy well the students must pay attention of their learning environment to create a comfortable learning environment. Table 5 discussed the aspect of student metacognition of the primary school teacher of Universitas Ahmad Dahlan, and it is known that the metacognitive aspect presented a low category. They refer to the metacognitive theory that metacognitive skills are different from one individual to another, and it is suitable with the ability of the thinking process. Student's metacognitive ability involves much conscious thinking in the learning process to optimise the learning process. Several things that affect the level of individual ability are 1) metacognitive ability is the knowledge regarding the thinking process that involves a personal perspective of cognitive ability; 2) metacognitive experience is the experience of cognition that accompanies and relates to cognitive activities which include failure and successfulness; 3) the strategy refers to specific thinking or attitude that used to implement the activities to achieve the goals.

The effort of lecturers and teachers in improving the low metacognitive aspect is by applying a metacognitive skill approach that consists of 1) goal setting, 2) the way to 
achieve the goals, 3) goal review, 4) thorough evaluation. By applying metacognitive skills, the students expected to be able to control the process of basic knowledge.

\section{CONCLUSION}

Based on the research result analysis, student skills of primary school teacher education of Faculty of Teacher Training and Education of Universitas Ahmad Dahlan state that their metacognitive ability presents a low-medium category. The answer that dominates all respondents about metacognitive abilities is appropriate (S). Judging from the cognitive knowledge aspect, the high category of the percentage calculation of cognitive knowledge aspects is in the declarative knowledge aspect. In the cognitive regulation aspect, planning becomes the highest percentage of cognitive regulation aspect. At the same time, the aspect of metacognitive ability presented the low category. Besides, in cognitive knowledge, the conditional aspect becomes the lowest category in all aspects. Meanwhile, in the cognitive regulation aspect, organising the information becomes the aspect that obtained the most significant percentage of the low category. Despite that, many factors related to student's metacognitive development have not maximised yet. The research result implies that the lecturer can implement a metacognitive approach customised by learning strategy based on the difference of the academics of every semester level.

\section{REFERENCES}

Afifi, R., Hindriana, A. F., \& Soetisna, U. (2016). Implementasi Project Based Learning Berbasis Praktikum Terhadap Keterampilan Dan Kesadaran Metakognitif Mahasiswa Calon Guru Biologi. Bioedusiana: Jurnal Pendidikan Biologi, 1(1), 29-45. http://jurnal.unsil.ac.id/index.php/bioed/article/view/75

Amin, A. M., Corebima, A. D., Zubaidah, S., \& Mahanal, S. (2020). European Journal of Educational Research The Correlation between Metacognitive Skills and Critical Thinking Skills at the Implementation of Four Different Learning Strategies in Animal Physiology Lectures. Effect. European Journal of Educational Research, 9(1), 143-163. https://doi.org/10.12973/eu-jer.9.1.143

Black, S. A., \& Schwartz, A. J. (2015). Learning: Behavior Grounded in Experiences. In Anesthesiology (Vol. 123, Issue 1, pp. 10-11). Lippincott Williams and Wilkins. https://doi.org/10.1097/ALN.0000000000000700

Blakey, E., \& Spence, S. (1990). Developing metacognition. RIC Clearinghouse on Information Resources.

Carpenter-Aeby, T., \& Aeby Victor G. (2013). Application of Andragogy to Instruction in an MSW Practice Class. Journal of Instructional Psychology, 40(1-4), 3-11. https://web.b.ebscohost.com 
Chiu, M. M. (2009). From Metacognition To Social Metacognition: Similarities, Differences, and Learning. Journal of Education Research, 3(4), 1-19. https://www.researchgate.net/publication/288305672

Conaway, W. (2009). Andragogy: Does one size fit all? A study to determine Adragogical principles' applicability to adult learners of all ages [Walden University]. https://scholarworks.waldenu.edu/dissertations

Corebima Aloysius, D., Susilo, H., \& Zubaidah, S. (2017). Creative Thinking of Low Academic Student Undergoing Search Solve Creates and Share Learning Integrated with Metacognitive Strategy. Article in International Journal of Instruction. https://doi.org/10.12973/iji.2017.10216a

Costillas, J. M. (2016). Eliciting and sustaining critical thinking through brain-based teaching in mathematics. Journal of Educational and Human Resource Development, 4, 50-55.

Demirel, M., Aşkın, İ., \& Yağcı, E. (2015). An Investigation of Teacher Candidates' Metacognitive Skills. Procedia - Social and Behavioral Sciences, 174, 1521-1528. https://doi.org/10.1016/j.sbspro.2015.01.783

Difrancesca, D., Nietfeld, J. L., \& Cao, L. (2016). A comparison of high and low achieving students on self-regulated learning variables. Learning and Individual Differences, 45, 228-236. https://doi.org/10.1016/j.lindif.2015.11.010

Dirgantoro, P. S. K. (2018). Pendekatan Keterampilan Metakognitif dalam Pembelajaran Matematika. M A T H L I N E : Jurnal Matematika Dan Pendidikan Matematika, 3(1), 1-10. https://doi.org/10.31943/mathline.v3i1.78

Efendi, N. (2013). Pengaruh Pembelajaran Reciprocal Teaching Dipadukan Think Pair Share Terhadap Peningkatan Kemampuan Metakognitif Belajar Biologi Siswa SMA Berkemampuan Akademik Berbeda Di Kabupaten Sidoarjo. Jurnal Santiaji Pendidikan, 3(2), 85-109 pp. http://jurnal.unmas.ac.id/index.php/JSP/article/view/14

Febrina, E., \& Mukhidin. (2019). Metakognitif sebagai Keterampilan Berfikir Tingkat Tinggi pada Pembelajaran Abad 21. Edusentris: Jurnal Ilmu Pendidikan Dan Pengajaran, 6(1), 25-32. https://doi.org/10.17509/EDUSENTRIS.V611.451

Hayati, W. I., Utaya, S., \& Astina, K. (2016). Efektivitas Student Worksheet Berbasis Project Based Learning Dalam Menumbuhkan Kemampuan Berpikir Kritis Siswa Pada Mata Pelajaran Geografi. Jurnal Pendidikan: Teori, Penelitian, Dan Pengembangan, 1 (3), 468474. https://doi.org/10.17977/JP.V113.6174

Henschke, J. A. (2011). Considerations Regarding the Future of Andragogy. Adult Learning, 22(1), 34-37. https://doi.org/10.1177/104515951102200109

Hsu, C. C., \& Wang, T. I. (2018). Applying game mechanics and student-generated questions to an online puzzle-based game learning system to promote algorithmic thinking skills. Computers and Education, 121, 73-88. https://doi.org/10.1016/j.compedu.2018.02.002 Iskandar, S. M. (2014). Pendekatan Keterampilan Metakognitif dalam Pembelajaran Sains di 
Kelas. ERUDIO, 2 (2), 13-20. https://erudio.ub.ac.id/index.php/erudio/article/view/151 Jiang, Y., Ma, L., \& Gao, L. (2016). Assessing teachers' metacognition in teaching: The Teacher Metacognition Inventory. Teaching and Teacher Education, 59, 403-413. https://doi.org/10.1016/j.tate.2016.07.014

Permendikbud No. 49 Tahun 2014 tentang Standar Nasional Pendidikan Tinggi, (2014).

Koriat, A., Ma'ayan, H., \& Nussinson, R. (2006). The intricate relationships between monitoring and control in metacognition: Lessons for the cause-and-effect relation between subjective experience and behaviour. Journal of Experimental Psychology: General, 135(1), 36-69. https://doi.org/10.1037/0096-3445.135.1.36

Loeng, S. (2018). Various ways of understanding the concept of andragogy. In Cogent Education (Vol. 5, Issue 1, pp. 1-15). Taylor and Francis Ltd. https://doi.org/10.1080/2331186X.2018.1496643

Maqsud, M. (1997). Effects of metacognitive skills and nonverbal ability on academic achievement of high school pupils. Educational Psychology, 17(4), 387-397. https://doi.org/10.1080/0144341970170402

Maryani, I., Putri, D. R., Urbayatun, S., Suyatno, \& Bhakti, C. P. (2020). Metacognition and integrated-project based learning (I-PjBL) in elementary schools. Universal Journal of Educational Research, 8(3), 1046-1054. https://doi.org/10.13189/ujer.2020.080339

Masino, S., \& Niño-Zarazúa, M. (2016). What works to improve the quality of student learning in developing countries? International Journal of Educational Development, 48, 53-65. https://doi.org/10.1016/j.ijedudev.2015.11.012

Memnun, D. S., Akkaya, R., \& Haciomeroglu, G. (2012). The Effect Of Prospective Teachers Problem Solving Beliefs On Self-Efficacy Beliefs About Mathematical Literacy. Journal of College Teaching \& Learning (TLC), 9(4), 289-298. https://doi.org/10.19030/tlc.v9i4.7299

Naimnule, L., \& Corebima, A. D. (2018). The Correlation between Metacognitive Skills and Critical Thinking Skills toward Students' Process Skills in Biology Learning. Journal of Pedagogical Research, 2(2), 122-134.

Oxman, S., \& Wong, W. (2014). White Paper: Adaptive Learning System. http://kenanaonline.com/files/0100/100321/DVx_Adaptive_Learning_White_Paper.pdf

Pintrich, P. R., \& De Groot, E. V. (1990). Motivational and Self-Regulated Learning Components of Classroom Academic Performance. Journal of Educational Psychology, 82 (1), 33-40. https://doi.org/10.1037/0022-0663.82.1.33

Saputri, W. (2017). Keterampilan Metakognitif Mahasiswa Calon Guru dan Hubungannya dengan Pola Pembelajaran Dosen . Didaktika Biologi: Jurnal Penelitian Pendidikan Biologi, 1 (2), 113-121. http://jurnal.um-palembang.ac.id/index.php/dikbio

Schraw, G, \& Dennison, R. S. (1994). Assessing Metacognitive Awareness. Contemporary Educational Psychology, 19, 460-475.

Schraw, Gregory, Olafson, L., Weibel, M., \& Sewing, D. (2012). Metacognitive Knowledge and 
Field-based Science Learning in an Outdoor Environmental Education Program (pp. 5777). Springer, Dordrecht. https://doi.org/10.1007/978-94-007-2132-6_4

Skinner, A., Blum, N., \& Bourn, D. (2013). Development Education and Education in International Development Policy: Raising Quality through Critical Pedagogy and Global Skills. Http://Journals.Openedition.Org/Poldev, 4.3 https://doi.org/10.4000/POLDEV.1654

Smith, K. E., \& Hudson, J. L. (2013). Metacognitive Beliefs and Processes in Clinical Anxiety in Children. Journal of Clinical Child and Adolescent Psychology, 42(5), 590-602. https://doi.org/10.1080/15374416.2012.755925

Sukmadinata, N. S. (2017). Metode Penelitian Pendidikan. Rosdakarya Remaja.

Veenman, M. V. J., Van Hout-Wolters, B. H. A. M., \& Afflerbach, P. (2006). Metacognition and learning: Conceptual and methodological considerations. In Metacognition and Learning (Vol. 1, Issue 1, pp. 3-14). Springer. https://doi.org/10.1007/s1 1409-006-6893-0

Zhao, N., Wardeska, J. G., McGuire, S. Y., \& Cook, E. (2014). Metacognition: An Effective Tool to Promote Success in College Science Learning. Journal of College Science Teaching, $43(4)$, 48-54. https://www.jstor.org/stable/43632012?casa_token=v6czj13A9KAAAAAA\%3ABbpyXnSzLK CWqkVwB7X6ZqMtdyog6G4fNnEbV_Etb_hDTsMRcEzOEOscRy8nIDPjqpE2t9RIfTIY2APnYSB MksiLluNWGD9quUTQU-fi3U-ucKp140c\&seq=1 \#metadata_info_tab_contents

Zimmerman, B. J., \& Martinez-Pons, M. (1990). Student Differences in Self-Regulated Learning: Relating Grade, Sex, and Giftedness to Self-Efficacy and Strategy Use. Journal of Educational Psychology, 82 (1), 51-59. https://doi.org/10.1037/0022-0663.82.1.51 